\title{
Roles of Double-professionally-titled Teachers in Innovation of Moral Education
}

\author{
Ming Sun \\ Zhuhai College of Jilin University \\ Zhuhai, Guangdong, China
}

\author{
Jingchuan $\mathrm{Fu}$ \\ Zhuhai College of Jilin University \\ Zhuhai, Guangdong, China
}

\author{
Yakun Yang \\ Jilin University \\ Changchun, Jilin, China
}

\begin{abstract}
Playing special roles in moral education of applied universities, double-professionally-titled teachers are helpful for improving professional moral education and teachers' ethical cultivation. It is favorable for exploring a new mechanism and model of moral education by developing highly qualified doubleprofessionally-titled teachers, strengthening teachers' ethical cultivation, developing standards and enhancing training/supervision and bringing positive roles of doubleprofessionally-titled teachers into play in applied universities.
\end{abstract}

Keywords-applied universities; moral education; doubleprofessionally-titled teachers; innovation

\section{INTRODUCTION}

Playing a transitional role in talent cultivation, applied universities have theoretical advantages of research-oriented universities and introduce practical characteristics of vocational technical colleges. They mainly foster highly qualified "theoretically applied" talents. It has been clearly pointed out in the Guiding Opinions on Transformation of Ordinary Universities for Undergraduates in Some Areas into Applied Ones (No. 7 Document issued in 2015) jointly released by the Ministry of Education, the National Development and Reform Commission and the Ministry of Finance that the cultivation of "double-professionally-titled double-qualification" teachers should be strengthened. Efforts should be actively made to introduce professionals recognized within different industries, recruit excellent professional technicians, management talents and highly skilled talents as leaders of professional construction and full-time or part-time teachers. Teachers should be selected and sent to receive trainings, work in some posts and practices according to plans." As inevitable choices of modern higher vocational education, double-professionally-titled teachers are important for fostering applied talents. Thus, they are great concerns that shall be greatly invested in training teachers for applied universities.

Double-professionally-titled teachers play important roles

Foundation program: a key funded program on innovation of moral education for schools of Guangdong Province in 2015 titled Promoting the Construction of a Long-term Mechanism for Moral Education of Private Universities by Teachers' Ethical Cultivation (Program No.: 2015DYYB029), hosted by $\mathrm{Fu}$ Jingchuan. in practical teaching. This is a starting and standing point from which applied universities attach importance to cultivation of double-professionally-titled teachers at present. With solid theoretical knowledge and certain scientific research skills, double-professionally-titled teachers don't only strong professional skills in practices and abundant job experiences, but are also familiar with professional ethics and comply with them. Clearly knowing position and roles of professional ethics in different industries, they play special roles in moral education of applied universities.

\section{IMPORTANT ROLES OF DOUBLE-PROFESSIONALLY- TITLED TEACHERS IN MORAL EDUCATION OF UNIVERSITIES}

\section{A. Helpful for Improving Professional Moral Education}

It is fundamental for education to establish morality and cultivate people. Highly qualified talents shall be fostered on the basis of sticking to moral education. As a generic term of moral concepts, moral sentiments and moral qualities necessary for occupations of practitioners as well as the ethical codes of conduct that shall be obeyed, professional ethics are effective for regulating various relationships within an occupation, among occupations, between occupations and society [1]. Socialist professional ethics generally cover enthusiasm about jobs, dedication, honesty, fairness in handling affairs, provisioning of services for the masses and contribution to the society. Professional moral qualities are important components of citizens' moral qualities. Moreover, professional moral education is a critical part of moral education in universities.

In applied universities, professional moral education plays a crucial role in improving university students' professional qualities, strengthening their competitiveness in employment and potential of career development. However, from practical professional moral education, it may be discovered that there still exist some problems that can't be ignored, which are mainly as follows. Firstly, inadequate importance is attached to professional moral education, which tends to be "marginal". Secondly, professional moral education is relatively backward compared with professional knowledge education and 
ideological/political education. Content of education is too empty and stylistic without social characteristics. Thirdly, professional moral education isn't special and pertinent, implemented by monotonous methods with unapparent teaching effects.

With special advantages in professional moral education, double-professionally-titled teachers are partially selected from excellent talents of enterprises and outstanding teachers who have been practically trained in enterprises. With abundant job experiences, all of them have more practically apprehended and deeply understood professional ethics of the society ruled by law and under the environment of market economy. They can't only deliver rich pertinent professional moral education in combination with their personal job experiences, but can also serve as models by setting examples in guiding students' internships. By improving students' professional ethics via the influences of what they constantly see and hear, they fundamentally solve the problem that professional moral education is separated from practices.

\section{B. Helpful for Improving Teachers' Ethical Cultivation}

In September 2014, current university teachers' morality was evaluated in the "Opinion on Establishing and Improving a Long-term Mechanism for Ethical Cultivation of University Teachers issued (No. 10 Document for teachers issued in 2014) by the Ministry of Education. "For a long time, university teachers have been loyal to educational undertakings, made painstaking efforts, selflessly devoted to the education, concentrated on studies, educated students, dared to assume their responsibilities and striven for innovation. They've made great contribution to reform and development of higher education, widely recognized and generally respected by the whole society. However, teachers are impacted by negative phenomena resulting from current social transformation. Some teachers' vague ideals/beliefs, weak awareness of education, perfunctory teaching, impetuous study atmosphere, even academic misconducts, unhealthy conducts and vices and so on have seriously harmed social images and professional reputation of teachers in universities. Some areas and universities haven't paid enough attention to teachers' ethical cultivation in a new era. They adopt obsolete and ineffective methods at work. [2]" In a new period, it is critically important and urgent to strengthen and improve teachers' ethical cultivation in universities and establish a complete long-term mechanism for such cultivation.

On 9th September, 2014, Xi Jinping, as the General Secretary of the Communist Party of China, made an important speech titled To Be Good Satisfactory Teachers of the Party and People in a symposium held with representatives of teachers and students from the Beijing Normal University. The General Secretary pointed out that "to be a good teacher with ideals and beliefs, one should be benevolent with moral sentiments and solid knowledge... Moral sentiments of good teachers were eventually reflected from their loyalty to and enthusiasm about their professions. [3]" Teachers' professional ethics are important indexes for measuring their professional qualities. In general, university teachers are mostly transferred among different universities and classrooms. In spite of receiving certain academic moral education, they have relatively fewer experiences of professional moral education. As a result, improvement of their professional qualities is objectively affected, thereby influencing overall university teachers' ethical cultivation.

For double-professionally-titled teachers with rich experiences of social practices, the key for them to succeed and become talents consists in their strict compliance with professional ethics. It is helpful for improving professional ethics of teachers by their ideas of showing great concern about professional ethics. Technological innovation talents, as parts of double-professionally-titled teachers, have persistently indulged in lawful and market-oriented management of intellectual properties at work, so they are highly selfdisciplinary in obeying academic ethics and serve as positive models for improving academic ethics of teachers. It is favorable for improving ethical cultivation of teachers in applied universities by bringing roles of excellent doubleprofessionally-titled teachers in practices as moral models.

\section{EThical CUltivation of Double-Professionally- TITLED TEACHERS}

As a writer of the Northern Song Dynasty, Su Zhe ever mentioned that "to criticize and educate others, one shall conduct himself well at first". Only if double-professionallytitled teachers have relatively good virtues, their positive roles in higher moral education can be given into full play. At present, the cultivation of double-professionally-titled teachers has been started relatively late with inadequate concerns. These teachers have insufficient experiences, and there are still some problems with the ethical cultivation of such teachers.

\section{A. Ignoring Investigation of Professional Ethics in Introducing and Cultivating Double-Professionally-Titled Teachers}

Currently, there is only a small amount of doubleprofessionally-titled ed teachers in applied universities, who are insufficient for meeting practical teaching demands of universities, so it is somewhat urgent to introduce and cultivate double-professionally-titled teachers. As a consequence, the introduction of double-professionally-titled teachers isn't strictly supervised in universities. Generally, importance is attached to investigate educational attainment and job experiences, whereas the investigation of professional ethics is easily neglected.

In addition, certain differences exist between universities' standards for teachers' ethics and social standards for professional ethics, which have separate unique characteristics. In universities, the Department of Personnel Management, related schools and departments usually fail to accurately grasp related specialized standards for professional ethics. Consequently, although professional ethics are considered in investigating talents by universities, it is hard to select excellent talents who meet standards for teachers' ethics and professional ethics. As a result, standards are relaxed and even some of them are discarded in marking hard choices. In this case, some moral hazards exist in introducing doubleprofessionally-titled teachers. 


\section{B. Lack of Training and Supervision of Ethical Cultivation for Double-Professionally-Titled Teachers}

In general, university teachers shall receive systematical pre-job educational trainings, including teachers' ethics. Nevertheless, for double-professionally-titled teachers, particularly full-time teachers from enterprises, the content and time of pre-job trainings are less and shorter than ordinary teachers. What's more, teachers' ethics are rarely involved in their trainings. As a consequence, double-professionally-titled teachers may hardly develop correct awareness of teachers' ethics within short time, especially characterized by lack of lofty professional ideals for education, insufficient care for students, weak awareness of services and non-meticulous attitudes toward teaching and scholarship. Some full-time teachers even can't act as models owing to their personal bad habits.

Double-professionally-titled teachers don't only assume teaching tasks, but also undertake certain work outside universities. Thus, they are hardly effectively supervised like full-time teachers in terms of their words and conducts. On one hand, double-professionally-titled teachers are usually considered as personnel "beyond system" by departments of teaching management. There is a lack of motives and means for supervising teachers' ethics. On the other hand, doubleprofessionally-titled teachers easily reckon teaching as their "second profession". They are reluctant to spend much energy in improving their ethics and qualities. All of these lead to isolation of double-professionally-titled teachers from ethical cultivation in universities.

\section{Impossibility to Give Positive Roles of Double- Professionally-Titled Teachers into Effective Play in Moral Education}

Although double-professionally-titled teachers have been taken into account as important components of talent and teacher cultivation in applied universities, moral education hasn't been further deeply reformed and innovated. From the perspective of theoretical research, roles of doubleprofessionally-titled teachers in moral education have been seldom explored in China. Less than 5 related dissertations, such as "Necessity for Private Universities to Give Roles of Part-time Teachers into Full Play" and "On Means of Ethical Cultivation for Part-time Teachers in Higher Vocational Colleges", can be retrieved in the CNKI. Moral education has been rarely mentioned in literature concerning doubleprofessionally-titled teachers either. In terms of management and practical work, managers of universities seldom separately consider ethical cultivation of double-professionally-titled teachers from the perspective of their special characteristics and rarely incorporate these teachers into innovation of moral education. In spite of fairly special and important roles of double-professionally-titled teachers in moral education of universities, particularly applied universities, such positive roles have been effectively brought into play due to their limited understanding and concern.
IV. StREnGTHENING ETHICAL CUltivation OF DOUBlePROFESSIONALLY-TITLED TEACHERS AND IMPROVING MORAL EDUCATION OF APPLIED UNIVERSITIES

For innovation of moral education, applied universities need to make full use of their resource advantages and actively establish new mechanism of moral education. It is effective for applied universities to improve their moral education by enhancing ethical cultivation of double-professionally-titled teachers and giving play to special positive roles of these teachers in moral education.

\section{A. Developing Ethical Standards for Double-Professionally- Titled Teachers}

To make sure that laws and regulations are available for double-professionally-titled teachers to obey in educational practices, ethical standards shall be developed for doubleprofessionally-titled teachers according to their special natures and based on those standards for ordinary teachers in applied universities. Meanwhile, admission standards and codes of conducts shall be clarified. It is helpful for healthy development of double-professionally-titled teachers by making ethical cultivation of these teachers standard, institutional and systematic.

Formation, development and change of teachers' ethics are restricted by general moral development of individuals [4]. In introducing double-professionally-titled teachers, morals of respondents are supposed to be deemed by applied universities as important indexes. These respondents shall be comprehensively evaluated pursuant to all indexes of "ethical standards for double-professionally-titled teachers", in order to select excellent teachers with both good virtues and abilities.

\section{B. Improving Mechanisms for Ethical Cultivation and Supervision of Double-Professionally-Titled Teachers}

It is a long-term process of "cultivation" and a process of progressively transforming heteronomy into self-discipline that integrates pre-job with post-job for the formation and development of teachers' morals, during which teachers shall keep on studying, comprehension, practising, adjustment and development [4]. In applied universities, teachers' moral education shall be incorporated into all school work, transformed into a routine and institutional practice. Besides, pre-job training, on-the-job education and regular summary shall be organically integrated. Efforts shall be made to bring exemplary roles of excellent teachers into play, help and guide double-professionally-titled teachers to improve their moral qualities and education. Furthermore, behavioral supervision of double-professionally-titled teachers shall be strengthened during their employment, in order to enhance their selfdiscipline and sense of responsibility.

It is necessary for applied universities to develop and improve the system for evaluating virtues of doubleprofessionally-titled teachers, in order that it may not only reflect universities' requirements and students' expectations, but also conform to practices of double-professionally-titled teachers. Being neither too high nor low, the standards shall be also operable. It is favorable for encouraging and warning 
double-professionally-titled teachers by integrating the evaluation system with these teachers' career development.

\section{Incorporating Double-Professionally-Titled Teachers into Moral Education System}

Ethical cultivation is strengthened for doubleprofessionally-titled teachers for the final purpose of improving talent cultivation and overall moral education. Applied universities shall not simply consider doubleprofessionally-titled teachers as complements of original faculty, but shall also fully recognize and highlight critical roles of double-professionally-titled teachers in cultivating applied talents, in order that such teachers may fully play their special roles in moral education.

Moral education is supposed to be rich in various forms, carried out by flexible methods with evident effects. Much attention shall be paid to combine moral education with social practices, professional learning, provisioning of services for the society and development of interests or hobbies, so as to develop multiple fully cooperative and interwoven forms of education. Incorporating double-professionally-titled teachers into moral education system, applied universities shall explore new mechanisms and models of moral education to improve professional moral education and ethical cultivation, opening up new ways for the innovation of moral education.

\section{REFERENCES}

[1] Wu Xiaohua. Strengthening University Students' Reflections on Professional Moral Education [J]. Leading Journal of Ideological \& Theoretical Education, 2014 (2): 118-121.

[2] Ministry of Education, Opinions on Establishing a Complete Long-term Mechanism for Ethical Cultivation of Teachers in Universities [Z]. (No. 10 Document for teachers issued in 2014).

[3] Xi Jinping. To Be Good Satisfactory Teachers of the Communist Party of China and People-A Speech in a Symposium with Representatives of Teachers and Students from the Beijing Normal University [N]. 9th September, 2014

[4] Fu Weili. On Teachers' Ethical Cultivation [J]. Journal of the Chinese Society of Education, 2001 (05) 